\title{
24 COVID-19 and American federalism
}

\author{
First-wave responses
}

John Kincaid and J. Wesley Leckrone

\subsection{Introduction}

The United States' response to COVID-19 marked an acute failure of cooperative federalism but did not alter the federal system because the federal government under President Donald Trump did not seek centralization; instead, he left the primary response up to the states in the fashion of dual federalism in which the federal and state governments occupy separate spheres of authority. This strategy was not ideal, as evidenced by the country's high numbers of COVID-19 casualties. But given President Trump's unwillingness to forge a cooperatively coherent federal-state-local response, states' constitutional authority to shut down much of the nation's economy limited a contagion that would have been more rampant absent this state authority. Another major factor handicapping the US response was partisan polarization, which pitted the Republican president against Democratic state and local officials, gridlocked Congress, and produced different pandemic policies in Democratic and Republican states and localities (Table 24.1).

\subsection{COVID-19 in the United States}

The United States experienced three waves of COVID-19 in 2020: spring, summer, and fall/winter. The last wave had, by far, the highest number of infections and deaths. As of 31 December 2020, the United States had recorded 19,943,605 COVID-19 cases (reaching 25,780,144 by 29 January 2021) and 344,497 deaths, which totaled 435,151 by 29 January 2021 (US Centers for Disease Control and Prevention 2021). The highest numbers of cases and deaths occurred from late October 2020 into January 2021.

The first confirmed US case occurred in Washington state on 20 January 2020 in a man who had visited Wuhan, China (although the United States only discovered the first case on 29 February). The first death was in northern California on 6 February.

Table 24.1 Key Statistics on COVID-19 in the United States of America as of 10 January 2021

\begin{tabular}{lllll}
\hline $\begin{array}{l}\text { Cumulative } \\
\text { Cases }\end{array}$ & $\begin{array}{l}\text { Cumulative Cases per } \\
\text { 100,000 Population }\end{array}$ & $\begin{array}{l}\text { Cumulative } \\
\text { Deaths }\end{array}$ & $\begin{array}{l}\text { Cumulative Deaths per } \\
\text { 100,000 Population }\end{array}$ & $\begin{array}{l}\text { Case Fatality } \\
\text { Percentage }\end{array}$ \\
\hline $21,761,186$ & $6,574.3$ & 365,886 & 110.5 & 1.7
\end{tabular}

Source: World Health Organization Weekly epidemiological update - 12 January 2021. Geneva: WHO, 2021. Available from https://www.who.int/publications/m/item/weekly-epidemiological-update 
However, the pandemic's epicenter was the commuter-linked states of Connecticut, New Jersey, and New York that pivot around New York City. On 31 December, these states, with 9.6 percent of the US population, still accounted for 18.2 percent of all US deaths despite the infection's nationwide spread. New York City had the highest death rate (300 per 100,000 population). New York, including New York City, had the highest state death rate (414 per 100,000 population); Vermont had the lowest (21). Among federal and quasi-federal countries on 31 January 2021, only Belgium (184.4 deaths per 100,000) and Bosnia and Herzegovina (140.7) had worse outcomes than the United States (134.3). Other health outcomes are still unknown because many people with non-COVID-19 conditions feared visiting medical facilities during the pandemic, while state governors' stay-at-home orders (SAHOs) probably increased Alzheimer deaths, suicides, domestic violence, depression, and other maladies.

Because most governors began issuing SAHOs in late March, the national unemployment rate leaped from 4.4 percent in March to 14.7 percent in April, then dropping monthly to 6.7 percent in November and December. The absence of a further drop in December was due largely to some governors' reimposition of SAHO's in response to the pandemic's third wave. This slowed the country's economic recovery. Some consumer-goods shortages appeared in late March, but supplies recovered to nearly normal levels by June. International air travel had virtually halted by 11 March, domestic air travel dropped 95 percent by 2 April, and most public interstate surface transportation shut down. However, domestic air travel had increased considerably by the Thanksgiving (26 November) and Christmas (25 December) holidays as millions of Americans disregarded advice against travel issued by the US Centers for Disease Control and Prevention (CDC). Economic recovery will take several years, although long-term economic damages are yet to be determined in terms of more homeless people, damaged careers, interrupted educations, permanent business closures, and perhaps greater income inequality.

\subsection{COVID-19 and federalism in the United States}

The United States has a dual federal system with three orders of government: national, state, and local, although local governments are the creatures of each state. The federal Constitution of 1788 is one of limited, delegated powers. All other powers are reserved to the states or the people. States retain the most authority to address public health emergencies through their police power, which is the authority to regulate citizens' health, safety, welfare, and morals. All states can enact declarations of emergency or disaster, and 35 states can declare public health emergencies. Such declarations authorize state officials to address pandemics. The federal government can address interstate and international infectious diseases through its commerce power. For example, the federal government lacks authority to require mask-wearing for everyone nationwide but can require mask-wearing on all federal-government land and property and on interstate transportation systems. Trump never issued such a mandate, but President Joseph Biden did so immediately after his 20 January 2021 inauguration. The US Public Health Services Act (1944), in conjunction with presidential executive orders, authorizes other forms of federal responsiveness, with the US Department of Health and Human Services at the forefront.

The states are mainly responsible for health care, but the federal government plays a large role. The United States has no universal health-care program. The national 
Medicare program covers all citizens age 65 and over, and Medicaid covers 73.5 million low-income people. Public-private arrangements under the US Affordable Care Act (2010) cover other low-income citizens. Hence, the two populations most vulnerable to COVID-19 mortality have government insurance. About 67.5 percent of citizens are covered by private insurance, which is mostly state-regulated, and about 9 percent lack health coverage. State and local governments own approximately 18.6 percent of all hospitals, while non-profit entities own 56.5 percent, and for-profit companies own 24.9 percent (Kaiser n.d.).

Although the United States ranked first on the 2019 Global Health Security Index, which evaluates capacity to address pandemics, investment in the US public health system languished over the pre-2020 decade. Funding for states' public health departments fell 16 percent per capita and 18 percent for local health departments. At least 38,000 jobs were lost in these fields, with more cutbacks occurring during the pandemic. Some health officials blamed these reductions for problems they faced setting up testing sites, building contact-tracing systems, distributing vaccines, and keeping vaccination records once vaccines become available (Weber et al. 2020).

\subsubsection{Management of health impact and response}

In mid-January 2020, the US CDC began screening for COVID-19 in travelers passing through the largest US international airports. On 31 January, the US Secretary of Health and Human Services declared a public health emergency, and President Trump barred entry of foreign nationals arriving from China. The president extended this ban to non-Americans travelling from Europe on 11 March. On 13 March, Trump issued 57 simultaneous disaster declarations for all states, Washington, DC, and US territories - the first all-state declaration in US history. The president indicated that the states should lead in combating COVID-19.

Initially, the nation experienced shortages of personal protective equipment for front-line responders, COVID-19 tests, and effective contact tracing. The CDC distributed contaminated test kits in March, requiring more than a month to rectify the problem. Once tests were available, they were in short supply, and processing backlogs delayed results for days. Ventilators were in short supply early in the outbreak, but Trump invoked the US Defense Production Act to require private industry to manufacture them. The president partnered with drug developers and manufacturers to accelerate vaccine development. This successful initiative, called Operation Warp Speed, enabled the US Food and Drug Administration to approve a vaccine developed by Pfizer on 11 December and a Moderna vaccine on 18 December. Trump also relaxed federal regulations to allow Medicare telehealth visits, ease hospital hiring of health workers, and decrease paperwork for federal health-care programs.

SAHOs were the most common tool used by governors, county officials, and mayors. California's Democratic Governor Gavin Newsom issued the first statewide SAHO on 19 March. However, San Francisco and five neighboring counties had issued the country's first SAHO on 16 March. From 19 March to 7 April, 43 governors - 24 Democrats and 19 Republicans - issued SAHOs of varying stringency and geographic scope. Of the first ten governors issuing SAHOs, nine were Democrats. All seven states having no SAHO had Republican governors. However, between 16 March and 1 April, 136 counties (i.e., non-municipal local governments in 48 states) nationwide, accounting for 66.9 million people, imposed SAHOs before their states (Brandtner et al. 2020). 
State and local SAHOs varied on prohibited activities and enforcement. Most required people to stay home except for "essential" work and personal activities. SAHOs shut down businesses and public services (e.g., mass transit) deemed "non-essential," though these varied by state and sometimes partisanship. For example, some Republican states tried to close abortion services as "non-essential"; Democratic states deemed them essential. Americans were limiting their activities before SAHOs due to infection fears, but political decisions on which businesses remained open changed consumer behavior, with commerce-driven to "essential" and online companies. SAHOs helped limit COVID-19's spread but caused economic damage as reflected in high unemployment.

Majorities of Americans supported mitigation, including state laws requiring mask-wearing. They endorsed social distancing, business restrictions, public gathering limits, a national strategy for reopening businesses and schools, a two-week national SAHO, and a ban on interstate travel (Mann 2020). However, Republicans expressed less concern than Democrats about COVID-19's severity, the consequences of economic reopening, and the need to wear masks and social distance. They also believed the president and the federal government were managing the pandemic effectively (Newport 2020; Ritter 2020). Nevertheless, only 23 percent of Americans approved of the federal government's pandemic management by August 2020, compared to 44 percent for the states' and 48 percent for local governments' management (Associated Press-NORC 2020).

\subsubsection{Management of fiscal impact and response}

The federal government has provided the bulk of pandemic fiscal stimuli. By large bipartisan margins, Congress enacted and Trump signed five COVID-19 relief bills from 6 March to 5 June. The Coronavirus Aid, Relief, and Economic Security (CARES) Act was the centerpiece, providing \$2.2 trillion in the largest stimulus in US history. CARES boosted the economy through direct payments to citizens, enhanced unemployment benefits, and funds for businesses. Adults in households earning less than $\$ 99,000$ per year received $\$ 1,200$ each and $\$ 500$ per child. Businesses were encouraged to retain workers through a $\$ 350$ billion Paycheck Protection Program that provided forgivable loans to smaller businesses.

CARES used a major intergovernmental program, Unemployment Compensation (UC), to help the jobless. The federal government sets parameters for UC, but states determine eligibility and benefits. CARES added $\$ 600$ per week to state benefits (which average \$320) and extended the benefits for up to 39 weeks (Adamczyk 2020; US Department of Labor 2019). However, despite the considerable increase in unemployed people, which overwhelmed state unemployment offices, no money was allocated to help states pay their share of UC. As of September, 20 states had borrowed more than $\$ 31.3$ billion from the federal government to cover their UC payments (Henderson 2020). The Federal Reserve (the US equivalent of a central bank) has accounted for about $\$ 7$ trillion in stimulus action to shore up banks and credit markets. It extended more than $\$ 2.3$ trillion in direct aid, including $\$ 500$ billion to keep credit flowing to state and local governments.

States might face a $\$ 555$ billion revenue shortfall through FY 2022 (Center for Budget 2020), although FY 2021 losses will range from about 1 percent in Idaho to perhaps 30 percent in New Mexico (National Conference 2020). Cities could 
experience a 13 percent revenue drop (McFarland and Pagano 2020). Revenue declines will likely be largest in Democratic jurisdictions, partly because of their stricter SAHOs. As of 7 December, Congress had provided state and local governments \$277 billion (Committee 2020).

States and the federal government have managed the economy dualistically. States shut down large swaths of the economy and reopened and closed down again at their own speeds. The federal government compensated with aid and stimulus spending. The aid conformed to past practices and did not increase centralization.

However, after 5 June, Democrats (who controlled the US House) and Republicans (who controlled the US Senate) deadlocked on additional spending despite pleas from the Federal Reserve and others. The House passed a \$3 trillion bill rejected by the Senate. The bipartisan National Governors Association requested $\$ 500$ billion more aid for state relief (National Governors 2020); the US Conference of Mayors requested \$250 billion more in direct aid to localities (Durr 2020). Democrats support more state-local aid. Most Republicans reject aid for state and local governments because they believe such aid would mainly benefit Democratic jurisdictions experiencing revenue losses due to their prolonged SAHOs and preCOVID-19 overspending. President Trump called Democratic states and cities “poorly run” (Bowden 2020), and the Senate's Republican Majority Leader Mitch McConnell suggested states seek bankruptcy rather than federal aid. While rejecting additional aid to state and local governments, Republicans supported funding for unemployment payments, small businesses, virus mitigation programs, and aid to education. Partisan disagreements over state-local aid, as well as Republicans' desire for COVID-19 liability protections for businesses operating during the pandemic, remained the primary obstacles to passing another comprehensive COVID-19 relief bill.

However, after intense negotiations following the presidential election of 3 November, Congress passed another COVID-19 measure - the \$915 billion Consolidated Appropriations/Response \& Relief Act - on 21 December, which Trump signed on 27 December after having threatened to veto it. The act did not provide direct general aid to state and local governments or provide COVID-19 liability protection for businesses, but it did provide considerable specific aid, such as $\$ 151$ billion for unemployment compensation, $\$ 54$ billion for elementary and secondary schools, $\$ 22$ billion for COVID-19 testing, tracing, and other mitigation, and \$28 billion for transportation.

\subsubsection{Intergovernmental relations}

Executive federalism has been contentious, but federal and state agencies' bureaucratic relations continued to be largely cooperative, except when the Trump administration interfered with some federal agencies' functioning. The United States has no umbrella intergovernmental institutions. Intergovernmental relations occur politically through informal party, associational, and customary channels and bureaucratically through hundreds of federal-state-local agency fora specific to policy areas (e.g., public health). The CDC has long-standing and highly institutionalized communication channels with state and local public-health agencies.

President Trump pushed states to lead the COVID-19 response. He made little effort to formulate a unified federal-government plan and a cooperative federalstate-local plan of action. The president criticized governors and mayors, mostly 


\section{4}

John Kincaid and J. Wesley Leckrone

Democrats, who refused to align their SAHO policies with his preferences. After retreating from an extraordinary claim that he had total authority to reopen state economies, Trump called recalcitrant governors "mutineers" (Arsova 2020) and tweeted such blasts as LIBERATE MINNESOTA (Trump 2020) in efforts to force governors to relax their SAHOs. Trump frequently contradicted public health officials, refused to wear a mask, held large campaign rallies without social distancing, and touted unproven drugs to combat COVID-19. In many states, governors and their secretaries of health became the main COVID-19 communicators. New York Democratic Governor Andrew Cuomo's daily press conferences gained national attention because the major media paired coverage of Trump's news conferences with Cuomo's briefings.

Interstate relations have been both competitive and cooperative. The lack of a national policy on acquiring and distributing many medical supplies induced competition for several months. States bid against each other in global markets for personal protective equipment, masks, and ventilators largely because Trump pitted them against each other when he admonished governors on 16 March to "try getting" medical supplies themselves (Sheth 2020) and claimed on 19 March that the federal government was not "a shipping clerk" (Forgey 2020). Michigan Democratic Governor Gretchen Whitmer's staff dubbed the resulting interstate competition "The Hunger Games" (Mahler 2020, p. 26). Prices spiked, and some state officials feared the federal government or other states would commandeer their incoming supplies during transit (Bender and Ballhaus 2020). By mid-April, the administration, believing it had done enough, executed a "state authority handoff" (Tankersley 2020). Production of medical protective gear began to reach demand in early summer, but some shortages returned as cases spiked again (Mulvihill and Fassett 2020). Although Trump lacked constitutional authority to close or open states' economies, he did not use his commanding media position to foster coherent, national leadership. Neither the president nor governors closed state borders, but many states required a 14-day quarantine for people entering their state from other states.

Similarly, following approval of the COVID-19 vaccines in December, the Trump administration agreed to distribute the vaccines to the states but left it up to the states to decide whether to follow CDC recommendations on how to prioritize vaccinations. However, the administration's inability to make reliable deliveries made it impossible for states to schedule vaccinations with predictability.

Some states developed working relationships. Governors organized regional agreements in the West (among three states), Northeast (seven states), and Midwest (seven states) to cooperate on reopening their economies and purchase medical supplies collaboratively. Seven other geographically dispersed states joined a pact to buy rapid tests in an effort to show companies there was demand for a quick roll-out of tests (Hogan 2020). States also shared medical equipment, and some waived licensing rules for out-of-state health personnel. Some local governments collaborated regionally to enforce COVID-19 restrictions, develop consistent business-closure policies, and formulate testing policies (Mallinson 2020).

Many states experienced state-local conflicts. State governments controlled by Republicans often sought to preempt SAHO policies instituted by Democratic county officials and city mayors. Republican county and city officials often resisted COVID-19 policies instituted by Democratically controlled state governments. Some elected county sheriffs refused to enforce state mask mandates and other rules. 


\subsubsection{Roles of state and local governments}

State and local governments continued delivering most services and switched to remote working and online public meetings fairly quickly in March and April. States implemented different SAHOs and reopening strategies, but regardless of their individual strategies, governors, county officials, and city mayors exercised emergency executive powers with little interference. Many lawsuits were filed, and some state legislatures objected to gubernatorial actions, but with little success. By December 2020, there were only four notably successful legal challenges: the Wisconsin Supreme Court ruled that a gubernatorial extension of the state's SAHO violated the state's constitution, the Michigan Supreme Court struck down the governor's SAHO and mask mandate, a US district court struck down the Pennsylvania governor's pandemic restrictions as violating the US Constitution (though the case remained on appeal as of this writing), and the US Supreme Court blocked New York's governor from enforcing an attendance limit on worship services.

Partisanship was prominent in states' COVID-19 policies, as illustrated in Figure 24.1. Democratic governors and local executives instituted earlier and more stringent SAHOs and reopened their economies more slowly than Republicans. Only 73 percent of the 26 Republican governors issued a SAHO. All Republican governors initiated reopening by 18 May, while states with Democratic governors waited until 9 June. There were also partisan divisions over mask-wearing mandates. All Democratic governors required masks by 1 August, while only 46 percent of Republican governors issued mask mandates by September.

Two factors influenced gubernatorial behavior. First, high population-density states, particularly in the Northeast, which typically had Democratic governors, were hit harder during the pandemic's early stages. However, New York's governor preempted the New York City mayor's authority to order a SAHO. This preemption delayed a statewide SAHO for five days in March and made New York City a COVID-19 super-spreader nationwide, substantially increasing the number

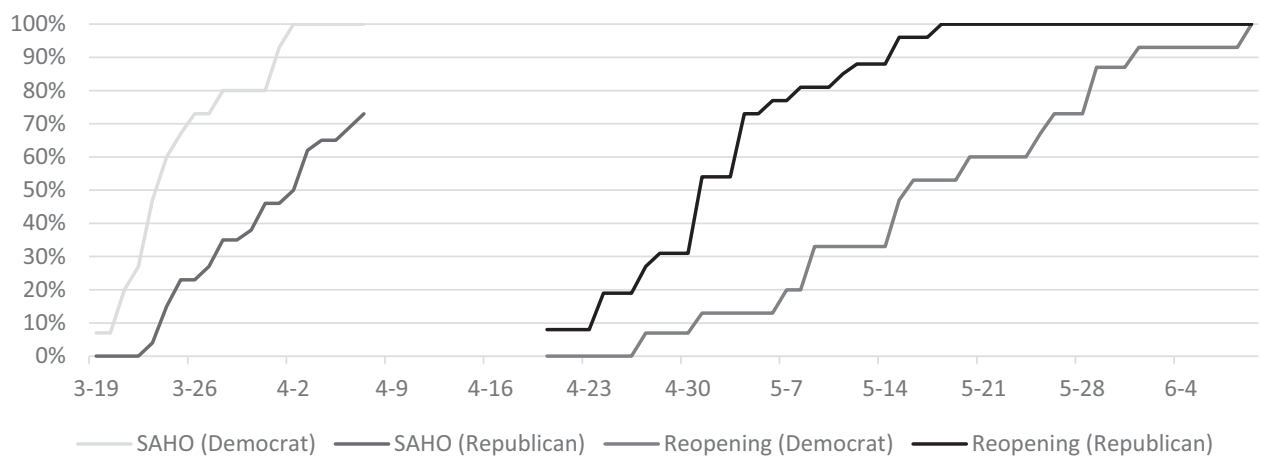

Figure 24.1 Dates of SAHOs and Reopenings by Gubernatorial Party in the United States of America.

Sources: Mervosh, S., Lu, D. and Swales, V., 2020. See Which States and Cities Have Told Residents to Stay at Home. New York Times, April 20. Available from: https://www.nytimes.com/interactive/2020/us/coronavirus-stay-at-home-order.html [Accessed 29 July 2020].

Lee, J. C., Mervosh, S., Avila, Y., Harvey B., Matthews, A. L., 2020. See How All 50 States Are Reopening (and Closing Again). New York Times. Available from: https://www.nytimes.com/interactive/2020/us/states-reopen-map-coronavirus.html [Accessed 29 July 2020]. 


\section{John Kincaid and J. Wesley Leckrone}

of US cases and deaths. Many states with Republican governors with more rural residents and lower population densities saw fewer COVID-19 cases. Second, many public officials throughout the federal system adopted a partisan framing of COVID-19. Democratic officials generally focused on curbing COVID-19 transmission through strict SAHOs and slow re-openings; Republicans emphasized SAHOs' economic costs and citizens' rights to comply voluntarily with public health measures.

States also varied by how governors exercised their authority. New York's Democratic governor centralized the pandemic response in his office, causing contentious relations with New York City's Democratic mayor. Numerous other states, many with Republican governors, placed loose restrictions on personal and business behavior, while preempting local governments from creating stricter standards. Maryland's Republican Governor Larry Hogan created statewide policies but worked collaboratively with local officials who wanted to reopen their economies more slowly than other areas in the state (Davidson and Haddow 2020). Governors who sought to maintain tight control did so mainly by threatening to withhold state and federal funds from counties or cities pushing to reopen in violation of their orders and revoke licenses and permits from businesses violating their orders.

Localities have been at the forefront of service provision for COVID-19's economic victims. Concern about community spread led places like New York City to house homeless people in hotels to keep them socially distanced. Many municipalities partnered with businesses and non-profits to provide meals to the poor and unemployed, and many school districts continued giving free meals to low-income children when schools closed and switched to remote learning. Localities also helped citizens connect to the Internet and avoid utility disruptions and housing evictions. Many provided assistance to small businesses hurt by SAHOs (National League of Cities n.d.). As of September, 45 states and 56 percent of big cities had implemented housing-eviction moratoriums; 40 percent of big cities and 54 percent of states provided rent relief; 66 percent of states and 19 percent of large cities enacted a foreclosure moratorium; 33 percent of big cities and 58 percent of states offered mortgage relief; and 30 percent of states and 37 percent of large cities provided some propertytax relief (Einstein, Palmer and Fox 2020). Michigan enacted a "Pay to Stay" law allowing local governments to lower delinquent-tax amounts, thus making it easier for owners to stay in their homes. Connecticut enacted a law allowing local governments to reduce interest rates on delinquent taxes; a few states allowed localities to delay or waive late payment penalties (Collins 2020). Elementary and secondary school closures were mandated or recommended in 48 states during spring 2020. However, most states provided flexibility to school districts and local health authorities to decide how to balance in-person and online instruction in the fall. As of mid-September, 73 percent of the 100 largest school districts were online only. Four states required their schools return to some form of in-person instruction as did four states again in 2021. As of 27 January 2021, nine of the country's 20 largest school districts were teaching only online, eight were fully in person, and three combined online and in-person instruction.

Overall, the United States managed COVID-19's third wave very poorly. During and after his re-election campaign, Trump virtually ignored the pandemic. States responded diversely, although, again, Democratic governors reimposed mild to severe SAHOs and mask mandates, while Republican governors took slower and less 
stringent action. Even while, for example, COVID-19 cases and deaths soared in South Dakota in November to the point where the state had the nation's sixth highest death rate by 31 January 2021, its Republican governor justified her refusal to issue a mask-wearing mandate as a vindication of personal freedom.

\subsection{Transformations in COVID-19 and federalism}

There has been no transformation in the practice of US federalism. There was an acute failure of cooperative federalism, which would have delivered a better pandemic response, but President-elect Joseph Biden will likely seek to institute a more cooperative federalist approach. System resilience was reflected in the ability of states to respond unilaterally with sweeping authority that closed much of the nation's economy. The imposition of statewide SAHOs was unprecedented in US history. It appears that SAHOs were blunt instruments, however, and that more targeted responses might prevail in the future.

Two potential developments might accelerate centralization. First, Democrats captured the White House and Congress in the 2020 elections. They will likely increase federal authority over pandemic responses. Because Americans expect the federal government to play a large role in responding to crises such as COVID-19, centralization will be aided by widespread public disapproval of ex-President Trump's and the federal government's COVID-19 management. Second, federal and state courts may curb states' SAHO authority on civil liberties grounds. This is emerging as a major litigation objective of various religious groups and civil libertarians.

However, increased centralization will likely intensify partisan polarization that could generate even more intergovernmental conflict during another pandemic. Polarization between Democratic and Republican elites and citizens has been the overwhelmingly predominant factor in the US federal system's poor response to COVID-19. Scholars have long noted the importance of parties in shaping federalism (Detterbeck, Renzsch and Kincaid 2015), and the US pandemic case starkly highlights this finding. Bipartisan cooperation is a necessary, if not sufficient, condition for cooperative federalism; consequently, the persistence of partisan polarization will hobble the ability of the federal system to respond more effectively to future domestic crises, including another pandemic.

\section{Bibliography}

Adamczyk, A., 2020. This is the Average Unemployment Insurance Payment in Every U.S. State Without the Extra $\$ 600$ in Federal Aid. CNBC, July 23. Available from: https://www. cnbc.com/2020/07/23/average-unemployment-insurance-payment-in-each-us-state.html

Arsova, P., 2020. Trump Calls Governors "Mutineers" for Creating Their Own Plans to Reopen the Economy. LaCorte News, 14 April. Available from: https://www.lacortenews. $\mathrm{com} / \mathrm{n} /$ trump-claims-total-authority-to-reopen-economy

Associated Press-NORC Center for Public Affairs Research, 2020. The August2020AP-NORC Center Poll. Available from: https://apnorc.org/wp-content/uploads/2020/08/AugustTopline-trump-1.pdf

Bender, M.C. and Ballhaus, R. B., 2020. How Trump Sowed Covid Supply Chaos: 'Try Getting It Yourselves'. Wall Street Journal, August 31. Available from: https://www. wsj.com/articles/how-trump-sowed-covid-supply-chaos-try-getting-it-yourselves11598893051 ?mod=trending_now_pos3 
Bowden, E., 2020. Trump Dismisses Bailouts for 'Poorly Run' States Led by Democrats. New York Post, April 27. Available from: https://nypost.com/2020/04/27/ trump-derides-coronavirus-bailouts-for-poorly-run-democratic-states/

Brandtner, C., Bettencourt, L.M.A., Berman, M.G. and Stier, A.J., 10 August 2020. Creatures of the State? Metropolitan Counties Compensated for State Inaction in Initial U.S. Response to Covid-19 Pandemic. Mansueto Institute for Urban Innovation Research Paper, University of Chicago. Available from: http://dx.doi.org/10.2139/ssrn.3670927

Center for Budget and Policy Priorities, 2020. Needed: Federal Aid to Reverse Deep PublicSector Job Cuts, Including in Education. CBPP, September 10. Available from: https://www. cbpp.org/blog/needed-federal-aid-to-reverse-deep-public-sector-job-cuts-including-ineducation

Collins, C., 2020. Property Tax Trends 2019 and 2020. Cambridge: Lincoln Institute of Land Policy. Available from: https://www.lincolninst.edu/sites/default/files/pubfiles/property_ tax_trends_report_2019-2020.pdf

Committee for a Responsible Federal Budget, 2020. "Update: COVID-Related State and Local Aid Will Total \$280 Billion.” 15 October. Available from: http://www.crfb.org/blogs/ update-covid-related-state-local-aid-will-total-280-billion

Conway, D., 2019. Percentage of People with Public Health Insurance Up in 11 States, Down in Two. Census.gov, November 7. Available from: https://www.census.gov/library/ stories/2019/11/state-by-state-health-insurance-coverage-2018.html

Davidson, N.M. and Haddow, K., 2020. State Preemption and Local Responses in the Pandemic. American Constitution Society Expert Forum, June 22. Available from: https:// www.acslaw.org/expertforum/state-preemption-and-local-responses-in-the-pandemic/

Detterbeck, K., Wolfgang, R. and Kincaid, J., eds., 2015. Political Parties and Civil Society in Federal Countries. Don Mills: Oxford University Press.

Durr, S., 2020. Mayors to President Trump: Cities Need Direct Financial Assistance Now. United States Conference of Mayors, August 5. Available from: https://www.usmayors. org/2020/08/05/mayors-to-president-trump-cities-need-direct-financial-assistance-now/

Education Week, 2020. Map: Where Are Schools Closed? Education Week, September 18. Available from: https://www.edweek.org/ew/section/multimedia/map-covid-19-schoolsopen-closed.html

Einstein, K. L., Maxwell, P. and Fox, S., 2020. COVID-19 Housing Policy. Initiative on Cities, Boston University. Available from: https://www.bu.edu/ioc/files/2020/10/BU-COVID19Housing-Policy-Report_Final-Oct-2020.pdf

Forgey, Q., 2020. 'We're Not a Shipping Clerk': Trump Tells Governors to Step up Efforts to Get Medical Supplies. Politico, 19 March. Available from: https://www.politico.com/ news/2020/03/19/trump-governors-coronavirus-medical-supplies-137658

Henderson, T., 2020. 20 State Borrow from Feds to Pay Unemployment Benefits. Stateline, September 21. Available from: https://www.pewtrusts.org/en/research-and-analysis/blogs/ stateline/2020/09/21/20-states-borrow-from-feds-to-pay-unemployment-benefits

Hogan, L., 2020. Governors of Maryland, Louisiana, Massachusetts, Michigan, Ohio and Virginia Announce Major Bipartisan Interstate Compact for Three Million Rapid Antigen Tests. Maryland.gov, August 4. Available from: https://governor.maryland.gov/2020/08/04/ governors-of-maryland-louisiana-massachusetts-michigan-ohio-and-virginia-announcemajor-bipartisan-interstate-compact-for-three-million-rapid-antigen-tests/

Kaiser Family Foundation, n.d. Hospital Ownership by Type. Available from: https:// www.kff.org/other/state-indicator/hospitals-by-ownership/?currentTimeframe=0\&sort Model=\%7B\%22colId\%22:\%22Location\%22,\%22sort\%22:\%22asc\%22\%7D [Accessed 1 September 2020].

Mallinson, D.J., 2020. Cooperation and Conflict in State and Local Innovation During COVID-19. American Review of Public Administration, 50 (6-7), 543-550.Mahler, J., 2020. In the Whirlwind. New York Times Magazine, 28 June, 20-29, 57. 
Mann, B., 2020. Despite Mask Wars, Americans Support Aggressive Measures to Stop COVID-19, Poll Finds. NPR Morning Edition, August 4. Available from: https://www.npr. org/2020/08/04/898522180/despite-mask-wars-americans-support-aggressive-measuresto-stop-covid-19-poll-fi

McFarland, C. and Michael, A.P., 2020. City Fiscal Conditions 2020. Washington, DC: National League of Cities. Available from: https://www.nlc.org/resource/city-fiscal-conditions-2020

Mulvihill, G. and Fassett, C., 2020. Protective Gear for Medical Workers Begins to Run Low Again. Associated Press, July 7. Available from: https://apnews.com/481d933 b0caa6f5fc61f466c86d4777b

National Conference of State Legislatures, 2020. Coronavirus (COVID-19): Revised State Revenue Projections. NCSL, September 10. Available from: https://www.ncsl.org/research/ fiscal-policy/coronavirus-covid-19-state-budget-updates-and-revenue-projections637208306. aspx

National Governors Association, 2020. National Governors Association Outlines Need for 'Additional and Immediate' Fiscal Assistance to States. National Governors Association, April 11. Available from: https://www.nga.org/news/press-releases/national-governorsassociation-outlines-need-for-additional-and-immediate-fiscal-assistance-to-states/

National League of Cities, n.d. COVID-19: Local Action Tracker. Available from: https:// covid19.nlc.org/resources/covid-19-local-action-tracker/

Newport, F., 2020. The Partisan Gap in Views of the Coronavirus. Gallup, May 15. Available from: https://news.gallup.com/opinion/polling-matters/311087/partisan-gap-viewscoronavirus.aspx

Ritter, Z., 2020. Republicans Still Skeptical of COVID-19 Lethality. Gallup, May 26. Available from: https://news.gallup.com/poll/311408/republicans-skeptical-covid-lethality.aspx

Sheth, S., 2020. 'Try Getting It Yourselves': Trump Told Governors They're Responsible for Getting Their Own Medical Equipment to Treat Coronavirus Patients. Business Insider, 16 March. Available from: https://www.businessinsider.com/coronavirus-trumptold-governors-get-medical-equipment-on-their-own-2020-3

Tankersley, J., 2020. No Virus Deaths by Mid-May? White House Economists Say They Didn't Forecast Early End to Fatalities. New York Times, May 6. Available from: https://www. nytimes.com/2020/05/06/business/coronavirus-white-house-economists.html

Trump, D.J., 2020. Tweet. 27 April. Available from: https://twitter.com/realDonaldTrump/ status/1251168994066944003?ref_src=twsrc\% 5Etfw\%7Ctwcamp\%5Etweetembed\%7Ctwterm\%5E1251168994066944003\%7Ctwgr\%5Eshare_3\&ref_url=https\%3A\% 2F\%2Fwww.businessinsider.com\%2Ftrump-tweets-to-liberate-michigan-minnesotaas-protesters-violate-orders-2020-4

U.S. Centers for Disease Control and Prevention, 2021. Trends in Number of COVID-19 Cases and Deaths in the US Reported to CDC, by State/Territory. Available from: https:// covid.cdc.gov/covid-data-tracker/\#trends_dailytrendscases

U.S. Department of Labor, May 2019. Unemployment Compensation: Federal-State Partnership. Available from: https://oui.doleta.gov/unemploy/pdf/partnership.pdf

Weber, L., Ungar, L., Smith, M. R., Recht, H. and Barry-Jester, A. M., 2020. Hollowed-Out Public Health System Faces More Cuts Amid Virus. Kaiser Health News, August 24. Available from: https://khn.org/news/us-public-health-system-underfundedunder-threat-faces-more-cuts-amid-covid-pandemic/

Wile, M., 2020. Congress Appropriates at Least \$1.05 Billion to States, Territories, Tribes to Combat COVID-19. National Conference of State Legislatures, March 6. Available from: https://www.ncsl.org/blog/2020/03/06/congress-appropriates-at-least-105-billion-to-statesterritories-tribes-to-combat-covid-19.aspx 